\title{
Author Correction: Effect of varying soil water potentials on methanogenesis in aerated marshland soils
}

\section{Dirk Wagner}

Correction to: Scientific Reports https://doi.org/10.1038/s41598-017-14980-y, published online 31 October 2017

The original version of this Article contained a typographical error in the Abstract.

"Under oxic conditions the CH4 production showed a dependence on the water content."

now reads:

"Under anoxic conditions the CH4 production showed a dependence on the water content.".

In addition, in the original version of this Article, Affiliation 1 was incorrectly listed as 'GFZ German Research Centre for Geosciences, Section 5.3 Geomicrobiology, Telegrafenberg, 14469, Potsdam, Germany' The correct affiliation is listed below:

GFZ German Research Centre for Geosciences, Section 5.3 Geomicrobiology, Telegrafenberg, 14473, Potsdam, Germany.

This has now been corrected in the PDF and HTML versions of the Article.

(i) Open Access This article is licensed under a Creative Commons Attribution 4.0 International cc) License, which permits use, sharing, adaptation, distribution and reproduction in any medium or format, as long as you give appropriate credit to the original author(s) and the source, provide a link to the Creative Commons license, and indicate if changes were made. The images or other third party material in this article are included in the article's Creative Commons license, unless indicated otherwise in a credit line to the material. If material is not included in the article's Creative Commons license and your intended use is not permitted by statutory regulation or exceeds the permitted use, you will need to obtain permission directly from the copyright holder. To view a copy of this license, visit http://creativecommons.org/licenses/by/4.0/.

(C) The Author(s) 2018

GFZ German Research Centre for Geosciences, Section 5.3 Geomicrobiology, Telegrafenberg, 14473, Potsdam, Germany. Correspondence and requests for materials should be addressed to D.W. (email: dirk.wagner@ gfzpotsdam.de) 